\title{
ANALISIS TINGKAT KREATIVITAS SISWA PADA MATA PELAJARAN FISIKA KELAS XII SMAS FERDY FERRY KOTA JAMBI
}

\author{
Puspa Cantika Riana \\ Program Studi Pendidikan Fisika, Universitas Jambi \\ Email: puspacantika28@gmail.com
}

DOI: http://dx.doi.org/10.29303/jpft.v5i2.1435

\begin{abstract}
Learning creativity is one of the important things in a learning process. The creativity of student in learning will greatly affect the student to obtain a success. This study aims to determine the level of student learning creativity at Jambi City Ferdy Ferry High School on physics subjects. The type of research method used is quantitative research with descriptive analysis. The instrument used was a learning independence questionnaire consisting of 23 statements using 4 likert scales. The subjects of this study were students of class XII Science 3 and XII Science 4 SMAS Ferdy Ferry Jambi City, which totaled 43 student. The results of the questionnaire data were processed using SPPS to get accurate data. The results showed that in class XII Natural Sciences 3 the category was never as much as $9.5 \%$ ( 2 of 21 students), the rare category was 33.3\% (7 of 21 students), the frequent category was $38.1 \%$ (8 out of 21 students), and the category was always as many as 19\% (4 of 21 students). And the results of research from class XII Science 4 categories never amounted to $9.1 \%$ (2 of 22 students), rare categories of $18.2 \%$ (4 of 22 students), frequent categories of 54.5\% (12 out of 22 students), and categories always amounted to $18.2 \%$ (4 out of 22 students). From the research that has been carried out it can be seen that students from both classes are at the same level of creativity.
\end{abstract}

Keywords: Education; Attitude; Creativity; Physics

\section{PENDAHULUAN}

Menurut (Sutrio et al. 2017) Ilmu pengetahuan alam (IPA) merupakan ilmu yang berkaitan dengan cara mencari tahu tentang alam secara sistematis sehingga IPA bukan hanya penguasaan kumpulan pengetahuan berupa fakta-fakta, konsepkonsep, atau prinsip-prinsip saja, tetapi juga merupakan suatu proses penemuan. IPA adalah ilmu pengetahuan yang mempelajari gejala-gejala melalui serangkaian proses yang dikenal dengan proses ilmiah, yang dibangun atas dasar sikap ilmiah dan hasilnya terwujud sebagai produk ilmiah yang tersusun atas tiga komponen terpenting berupa konsep, prinsip, dan teori yang berlaku secara umum. Konsep yang dimaksud adalah ide yang mempersatukan fakta-fakta atau dengan kata lain konsep merupakan suatu penghubung antara faktafakta yang saling berhubungan. Kemudian prinsip adalah hubungan antara konsepkonsep yang berkaitan, sedangkan teori adalah berbagai prinsip yang dapat menjelaskan fenomena alam. Mata pelajaran fisika merupakan salah satu cabang dari IPA dan merupakan ilmu pengetahuan yang mempelajari fenomena alam melalui berbagai proses ilmiah. Menurut (Pebriyanti, 2015) Fisika pada jenjang SMA memiliki beberapa tujuan, diantaranya adalah agar peserta didik memiliki kemampuan: (1) mengembangkan kemampuan bernalar dalam berfikir analisis induktif dan deduktif dengan menggunakan konsep dan prinsip fisika untuk menjelaskan berbagai peristiwa alam dan penyelesaian masalah baik secara kualitatif maupun kuantitatif; (2) menguasai konsep dan prinsip fisika serta mempunyai keterampilan mengembangkan ilmu pengetahuan dan teknologi. Menurut (Hidayatullah et al. 2018) Fisika merupakan bagian dari sains yang memfokuskan kajiannya pada materi, energi, dan hubungan antara keduanya. Sains tidak hanya terdiri dari kumpulan yang terisolasi satu dengan lainnya melainkan kumpulan ilmu pengetahuan yang terorganisasi secara 
sistermatis. Pendidikan fisika menekankan pada pemberian pengalaman langsung untuk mengembangkan kompetensi agar siswa mampu menjelajahi dan memahami alam sekitar secara ilmiah. Pendidikan fisika diarahkan untuk "mencari tahu" dan "berbuat" sehingga dapat membantu siswa untuk memperoleh pemahaman yang lebih mendalam tentang alam sekitar (Sambada, 2012). Salah satu alternatif pemecahan masalah pada pembelajaran fisika adalah kreativitas siswa.

Kreativitas merupakan suatu kemampuan mental seseorang dalam memandang suatu hal dari sudut pandang lain. Kreativitas terbentuk dengan adanya pemikiran yang berbeda dari seorang individu. Pemikiran kreatif perlu dilatih karena mampu membuat anak lancar dan luwes (fleksibel) dalam berpikir, mampu melihat suatu masalah dari berbagai sudut pandang, dan mampu melahirkan banyak gagasan (Smarabawa et al. 2013). Sifat kreatif timbul secara spontan berdasarkan segala pengalaman yang pernah dialami seseorang. Menurut (Sugihartono et al. 2007) mengartikan kreativitas sebagai kemampuan mental yang khas pada manusia yang melahirkan pengungkapan yang unik, berbeda, orisinil, baru, indah, efisien, tepat sasaran dan tepat guna. Kreativitas merupakan suatu tuntutan pendidikan dan kehidupan yang sangat penting pada saat ini. Kreativitas akan menghasilkan berbagai inovasi dan perkembangan baru dalam suatu kehiduapan. Individu dan organisasi yang kreatif akan selalu dibutuhkan oleh lingkungannya karena mereka dapat mampu memenuhi kebutuhan lingkungan yang terus berubah dan mampu untuk bertahan dalam kompetisi global yang dinamis dan ketat. Kreativitas anak yang tinggi mendorong anak belajar dan berkarya lebih banyak sehingga suatu hari mereka dapat menciptakan hal-hal baru diluar dugaan.
Seseorang yang memiliki keativitas selalu berpikir luas dalam mengembangkan gagasannya.

Kreativitas belajar merupakan salah satu hal yang penting dalam suatu proses pembelajaran. Karena, kreativitas belajar dapat melatih peserta didik untuk tidak bergantung pada orang lain. Jika seseorang itu mempunyai kreativitas yang tinggi cenderung orang tersebut akan lebih kreatif dan menghasilkan sesuatu yang positif. Kreativitas seorang peserta didik dalam belajar akan sangat mempengaruhi peserta didik tersebut untuk memperoleh suatu keberhasilan. Peserta didik yang mempunyai kreativitas yang tinggi maka peserta didik ituakan mempunyai pandangan yang luas dalam belajarnya, sehingga hal tersebutakan berdampak pada tinggi rendahnya mutu pembelajaran peserta didik. Kemampuan berpikir kreatif merupakan salah satu komponen kognitif peserta didik yang menunjang keberhasilan mereka. Meskipun demikian, kreativitas cenderung jarang sekali diperhatikan dalam pembelajaran fisika (Rohaeti et al. 2018). Menurut (Istianah, 2013) Terdapat empat tahap dalam berpikir kreatif, yaitu; (1) Exploring, mengidentifikasi hal-hal apa saja yang ingin dilakukan dalam kondisi yang ada pada saat ini; (2) Inventing, melihat atau mereview berbagai alat, teknik, dan metode yang telah dimiliki yang mungkin dapat membantu dalam menghilangkan cara berpikir yang tradisional; (3) Choosing, mengidentifikasi dan memilih ide-ide yang paling mungkin untuk dilaksanakan; (4) Implementing, bagaimana membuat suatu ide dapat diimplementasikan.

Kreativitas sebagai kemampuan untuk melihat kemungkinan-kemungkinan untuk memecahkan suatu masalah, merupakan bentuk pemikiran yang sampai saat ini masih kurang mendapat perhatian dalam pendidikan formal. Siswa lebih 
dituntut untuk berpikir linier, logis, penalaran, ingatan atau pengetahuan yang menuntut jawaban paling tepat terhadap permasalahan yang diberikan. Menurut (Munandar, 2009) Kreativitas yang menuntut sikap kreatif dari individu itu sendiri perlu dipupuk untuk melatih anak berpikir luwes (flexibility), lancar (fluency), asli (originality), menguraikan (elaboration) dan dirumuskan kembali (redefinition) yang merupakan ciri berpikir kreatif.

Dalam kenyataannya, kreativitas siswa dalam fisika belum diperhatikan oleh guru. Akan tetapi, kegiatan pembelajaran sudah difokuskan pada siswa. Siswa dibentuk dalam kelompok belajar dan bertanggung jawab atas LKS yang diberikan guru. Namun soal yang diberikan sebatas pada materi yang diajarkan yang telah didahului dengan contoh oleh guru, bukan merupakan masalah fisika. Pemberian soal rutin seperti itu membuat siswa hanya menguasai teknik penyelesaian yang sudah dicontohkan sebelumnya dan tidak memberikan ruang bagi siswa berkreasi dengan pengalaman fisika sebelumnya.

Kreativitas dapat dikembangkan dengan mengkondisikan siswa untuk aktif terlibat langsung selama proses pembelajaran. Pengembangan kreativitas pada siswa dapat dilakukan melalui proses belajar diskaveri/inkuiri dan belajar bermakna, dan tidak dapat dilakukan hanya dengan kegiatan belajar yang bersifat ekspositori, karena inti dari kreativitas adalah pengembangan kemampuan berpikir divergen dan bukan berpikir konvergen (Sukmadinata, 2003). Kenyataan ini mengharuskan guru untuk dapat memotivasi dan memunculkan kreativitas peserta didik selama pembelajaran berlangsung dengan menggunakan beberapa metode, strategi yang bervariasi, misalnya melalui pembelajaran kerja kelompok, bermain peran, dan pemecahan masalah.
Pengembangan kreativitas dapat terukur melalui ciri aptitude dan ciri nonaptitudenya. Menurut (Munandar, 2004), Ciri-ciri aptitude dari kreativitas (berpikir kreatif) meliputi: (1) keterampilan berpikir lancar (kelancaran), (2) keterampilan berpikir luwes (fleksibel), (3) keterampilan berpikir orisinal (orisinalitas), (4) keterampilan memperinci (elaborasi), (5) keterampilan menilai (evaluasi). Sedangkan ciri-ciri non aptitude yaitu: (1) rasa ingin tahu, (2) bersifat imajinatif, (3) merasa tertantang oleh kemajemukan, (4) sifat berani mengambil risiko, (5) sifat menghargai.

Penelitian ini dilakukan di Sekolah Menengah Atas (SMA) Swasta Ferdy Ferry Kota Jambi. Peneliti melakukan studi pendahuluan tentang masalah kreativitas siswa dalam proses pembelajaran fisika di sekolah dan di rumah melalui penyebaran angket karakter siswa. Angket karakter itu sendiri terdiri dari 18 karakter salah satunya adalah "kreativitas". Masalah kreativitas belajar yang terjadi di sekolah merupakan sebuah masalah yang penting untuk diselesaikan karena jika masalah tersebut tidak terselesaikan mengakibatkan tujuan pendidikan tidak tercapai dan siswa tidak mampu mengembangkan potensi secara optimal. Oleh karena itu penelitian ini bertujuan untuk mengetahui tingkat kreativitas belajar siswa di SMAS Ferdy Ferry Kota Jambi terhadap mata pelajaran fisika.

Penelitian ini dilakukan di SMAS Ferdy Ferry Kota Jambi. Peneliti melakukan studi pendahuluan tentang masalah kreativitas siswa di sekolah dan kreativitas siswa di rumah melalui penyebaran angket karakter siswa. Angket karakter itu sendiri terdiri dari 18 karakter salah satunya adalah "kreativitas". Masalah kreativitas belajar yang terjadi di sekolah merupakan sebuah masalah yang penting untuk diselesaikan karena jika masalah tersebut tidak 
terselesaikan mengakibatkan tujuan pendidikan tidak tercapai dan siswa tidak mampu mengembangkan potensi secara optimal. Oleh karena itu penelitian ini bertujuan untuk mengetahui tingkat kreativitas belajar siswa di SMAS Ferdy Ferry Kota Jambi terhadap mata pelajaran fisika.

\section{METODE PENELITIAN}

Pada penelitian ini di gunakan jenis penelitian kuantitatif. Dimana penelitian ini di lakukan pada tanggal 21 Oktober 2019 pada kelas XII IPA 3 dan kelas XII IPA 4 di SMAS Ferdy Ferry Kota Jambi Tahun Ajaran 2019/2020 terhadap mata pelajaran Fisika.

Tabel 1. Jumlah Subjek Penelitian

\begin{tabular}{cc}
\hline Kelas & Jumlah Siswa \\
\hline XII IPA 3 & 21 siswa \\
\hline XII IPA 4 & 22 siswa \\
\hline Total & 43 siswa \\
\hline
\end{tabular}

Intrumen penelitian ini yaitu angket. Angket merupakan teknik pengumpulan data yang dilakukan dengan cara memberikan seperangkat pertanyaan atau pernyataan tertulis kepada responden untuk dijawab. Menurut (Hardiyanti, 2018) Tujuan penyebaran angket ialah mencari informasi yang lengkap mengenai suatu masalah dari responden tanpa merasa khawatir bila responden memberi jawaban yang tidak sesuai pernyataan dalam pengisian daftar pertanyaan. Dalam penlitian ini, angket digunakan untuk mengetahui sikap kedisiplinan siswa terhadap mata pelajaran fisika angket diberikan kepada siswa SMAS Ferdy Ferry Kota Jambi. Angket yang akan diberikan bersifat tertutup dan terdiri dari 23 pernyataan. Angket ini menggunakan skala likert. Skala likert digunakan untuk mengukur sikap, pendapat, dan presepsi seseorang atau sekelompok orang tentang fenomena soaial. Skala tersebut menggunakan skala empat yaitu Selalu (SL) diberi skor 4, Sering (SR) diberi skor 3, Jarang (JR) diberi skor 2 dan Tidak Pernah (TP) diberi skor 1.

Dalam penelitian kuantitatif, teknis analisis data merupakan kegiatan setelah data dari seluruh responden terkumpul. Kegiatan dalam analisis data adalah mengelompokkan data berdasarkan variabel dan jenis responden, mentabulasi data berdasarkan variabel dari seluruh responden, menyajikan data tiap variabel yang diteliti, malakukan perhitungan untuk menjawab rumusan masalah. Berikut langkah-langkah teknis analisis data yang ditempuh dalam penelitian ini :

1. Menentukan skor dari masing-masing alternatif jawaban yang sudah diberikan oleh responden dengan memberikan skor masing-masing butir skala item dari angka 1 sampai angka 4 berdasarkan norma scoring yang berlaku dengan melihat sifat pernyataan favourable dan unfavourable.

2. Membuat tabulasi skor dari item-item kuesioner dan menghitung skor masingmasing subjek serta total skor item. Melakukan scoring dengan bantuan Microsoft Excel dan menganalisis data statistik menggunakan program IBM SPSS Statistics 23.

Tabel 2. Tabulasi data

\begin{tabular}{cc}
\hline Alternatif Respon & Skor \\
\hline Tidak Pernah & 1 \\
\hline Jarang & 2 \\
\hline Sering & 3 \\
\hline Selalu & 4 \\
\hline
\end{tabular}

3. Membuat kategori tingkat kreativitas terhadap mata pelajaran fisika siswa SMAS Ferdy Ferry Kota Jambi. Kategori disusun berdasarkan distribusi normal dengan metode kategori jenjang atau ordinal. Kategori jenjang bertujuan untuk menempatkan individu kedalam 
kelompok-kelompok yang posisinya berjenjang menurut suatu kontinum berdasarkan atribut yang diukur.

Untuk menentukan jarak interval digunakan persamaan:

$$
i=\frac{\text { skor tertinggi }- \text { skor terendah }}{\text { jumlah kelas interval }}
$$

Keterangan:

$\mathrm{i}=$ Interval

Sehingga dapat diperoleh kategori kreativitas belajar siswa pada mata pelajaran fisika tabel 3 dibawah ini.

Tabel 3. Kategori Kreativitas Belajar

\begin{tabular}{cc}
\hline Interval Skor & Kategori \\
\hline $45-53$ & Tidak Pernah \\
\hline $54-61$ & Jarang \\
\hline $62-69$ & Sering \\
\hline $70-77$ & Selalu \\
\hline
\end{tabular}

\section{HASIL DAN PEMBAHASAN}

Kreativitas merupakan suatu kemampuan mental seseorang dalam memandang suatu hal dari sudut pandang lain. Kreativitas terbentuk dengan adanya pemikiran yang berbeda dari seorang individu. Kreativitas belajar merupakan salah satu hal yang penting dalam suatu proses pembelajaran. Karena, kreativitas belajar dapat melatih peserta didik untuk tidak bergantung pada orang lain. Kreativitas seorang peserta didik dalam belajar akan sangat mempengaruhi peserta didik tersebut untuk memperoleh suatu keberhasilan. Dimana tujuan kreativitas yaitu untuk mengekspresikan diri melalui hasil karya dengan menggunakan teknikteknik yang dikuasai dan mampu menemukan cara alternatif dalam pemecahan masalah.

Penelitian ini bertujuan untuk menganalisis sikap kreativitas siswa pada kelas XII IPA 3 dan kelas XII IPA 4
SMAS Ferdy Ferry Kota Jambi. Menurut (Widiyanto, 2013) Statistika merupakan istilah yang berasal dari bahasa italia statista yang berarti negarawan, statistika digunakan dalam segala bidang ilmu dan kehidupan manusia. Pada dasarnya statistika terbagi menjadi dua yaitu statistika murni dan statistika deskriptif. Statistika deskriptif ialah statistika yang digunakan hanya untuk menganalisis data dan menggambarkan sekelompok data hasil penelitian yang tidak digunakan dalam pengambilan kesimpulan luas. Menurut (Muschon,2013) Statistika membahas cara-cara pengumpulan, peringkasan, penyajian data sehingga diperoleh informasi yang lebih mudah dipahami. Pada statistika deskriptif memuat tentang mean, median, modus, nilai minimum, nilai maksimum, standar deviasi, range, kuartil, persentil, dan lainlain.

Penelitian ini menggunakan uji statistik deskriptif, dimana membuat sebuah angket karakter yang terdiri dari 23 pernyataan. Angket karakter tersebut disebarkan kepada siswa SMAS Ferdy Ferry Kota jambi yaitu pada kelas XII IPA 3 dan kelas XII IPA 4. Penyebaran angket tersebut bertujuan untuk mengetahui bagaimana tingkat kreativitas belajar siswa di SMAS Ferdy Ferry Kota Jambi terhadap pembelajaran Fisika.

Setalah mendapatkan data-data yang dibutuhkan selanjutnya yang dilakukan adalah mengolah data tersebut dan mencari nilai statistiknya untuk melihat perbandingan sesuai dengan metode yang digunakan. Statistik yang digunakan ialah statistik deskriptif yaitu mencari nilai mean, median, modus, nilai minimum, nilai maksimum, dan standar deviasi. Berikut ini adalah hasil statistik deskriptif angket kedisiplinan untuk kelas XII IPA 3. 
Tabel 4. Analisis Kreativitas Siswa Kelas XII IPA

\begin{tabular}{|c|c|c|c|c|c|c|c|c|c|}
\hline Kategori & Rentang & Mean & Median & Modus & $\begin{array}{l}\text { Standar } \\
\text { Deviasi }\end{array}$ & Min & Max & Jumlah & $\%$ \\
\hline Tidak & $45-53$ & & & & & & & & \\
\hline Pernah & & & & & & & & 2 & 9.5 \\
\hline Jarang & $54-61$ & 62.5238 & 63.00 & 55 & 7.30492 & 50 & 77 & 7 & 33.3 \\
\hline Sering & $62-69$ & & & & & & & 8 & 38.1 \\
\hline Selalu & $70-77$ & & & & & & & 4 & 19.0 \\
\hline & \multicolumn{7}{|c|}{ Jumlah } & 21 & $100 \%$ \\
\hline
\end{tabular}

Dari hasil data pada Tabel 4 di atas dapat dilihat untuk setiap nilai-nilai statistika yang diperoleh secara keseluruhan untuk kelas XII IPA 3 SMAS Ferdy Ferry Kota Jambi hanya memfokuskan pada nilai mean, median, modus, standar deviasi, nilai minimum, dan nilai maksimum. Dari data di atas diperoleh bahwa nilai mean di peroleh 62.5238 , nilai mediannya diperoleh 63 , nilai yang sering muncul (modus) diperoleh 55, nilai minimum diperoleh 50, nilai maksimum diperoleh adalah 77 dan standar deviasi nya adalah 7.30492. Hal ini menunjukkan bahwa nilai mean dapat digunakan sebagai representasi dari keseluruhan data, yang berarti mengindikasikan hasil yang baik. Sementara kategori sikap kreativitas belajar siswa terhadap Fisika menunjukkan: kategori tidak pernah sebanyak 9.5\% (2 dari 21 siswa), kategori jarang sebanyak $33.3 \%$ (7 dari 21 siswa), kategori sering sebanyak $38.1 \%$ (8 dari 21 siswa), dan kategori selalu sebanyak 19\% (4 dari 21 siswa). Dari persentasi tersebut menunjukkan bahwa banyak siswa yang kreatif dalam proses belajar fisika. Semua perolehan nilai-nilai tersebut didapatkan dari hasil pengisian angket yang telah diisi oleh siswa kelas XII IPA 3 SMAS Ferdy Ferry Kota Jambi sebanyak 21 siswa.
Selanjutnya yaitu hasil statistik deskriptif angket kedisiplinan untuk kelas VII E SMP Negeri 14 Kota Jambi diperoleh:

Pada data kedua diambil dari kelas XII IPA 4 SMAS Ferdy Ferry Kota Jambi yang berjumlah 22 siswa. Yang dilakukan pada data kelas XII IPA 4 ini sama halnya dengan data kelas XII IPA 3 yaitu menentukan nilai-nilai statistik. Nilai- nilai statistik yang diolah adalah standar deviasi, mean, media, modus, nilai minimum, dan nilai maksimum.

Dari data statistik deskriptif pada Tabel 4 diatas diperoleh bahwa mean sebesar 64.2273; median sebesar 67.5000; dan modus sebesar 68. Selain itu diperoleh juga standar deviasi sebesar 6.68995 yaitu lebih kecil dari mean. Hal ini juga menunjukkan bahwa nilai mean dapat digunakan sebagai representasi dari keseluruhan data, yang berarti mengindikasikan hasil yang baik. Sementara kategori sikap motivasi belajar siswa terhadap Fisika menunjukkan: kategori tidak pernah sebanyak $9.1 \%$ (2 dari 22 siswa), kategori jarang sebanyak $18.2 \%$ (4 dari 22 siswa), kategori sering sebanyak 54.5\% (12 dari 22 siswa), dan kategori selalu sebanyak 18.2\% (4 dari 22 siswa). Dari persentasi tersebut menunjukkan bahwa banyak siswa yang kreatif dalam proses belajar fisika. 
Tabel 5. Analisis kreativitas siswa kelas XII IPA 4

\begin{tabular}{|c|c|c|c|c|c|c|c|c|c|}
\hline Kategori & Rentang & Mean & Median & Modus & $\begin{array}{c}\text { Standar } \\
\text { Deviasi }\end{array}$ & Min & Max & Jumlah & $\%$ \\
\hline $\begin{array}{l}\text { Tidak } \\
\text { Pernah }\end{array}$ & $45-53$ & \multirow{4}{*}{$\begin{array}{c}64.227 \\
3\end{array}$} & \multirow{4}{*}{67.5000} & \multirow{4}{*}{68.00} & \multirow{4}{*}{6.68995} & \multirow{4}{*}{45} & \multirow{4}{*}{71} & 2 & 9.1 \\
\hline Jarang & $54-61$ & & & & & & & 4 & 18.2 \\
\hline Sering & $62-69$ & & & & & & & 12 & 54.5 \\
\hline Selalu & $70-77$ & & & & & & & 4 & 18.2 \\
\hline \multicolumn{8}{|c|}{ Jumlah } & 22 & $100 \%$ \\
\hline
\end{tabular}

Dari kedua data diatas dapat dilihat bahwa pada setiap siswa memiliki kreativitas yang berbeda-beda antara satu dengan yang lainnya di bidang kreativitas siswa di dalam kelas maupun di rumah. Ada siswa yang memiliki kreativitas yang tinggi dan ada pula siswa yang memiliki kreativitas yang rendah. Menurut (Yoga, 2013) Tingkat kreativitas yang rendah tidak semata-mata karena dia tidak memiliki sikap kreatif pada dirinya tetapi ada banyak hal yang mempengaruhinya, misalnya faktor keluarga atau lingkungan sekitar yang tidak menanamkan sikap kreatif kepadanya terhadap apa yang dilakukannya. Meskipun demikian kreativitas dapat dikembangkan dengan mengkondisikan siswa untuk aktif terlibat langsung selama proses pembelajaran.

\section{PENUTUP}

Kreativitas merupakan suatu kemampuan mental seseorang dalam memandang suatu hal dari sudut pandang lain. Kreativitas belajar merupakan salah satu hal yang penting dalam suatu proses pembelajaran. Karena, kreativitas belajar dapat melatih peserta didik untuk tidak bergantung pada orang lain. Fisika merupakan pelajaran yang memberikan pengetahuan tentang alam semesta untuk berlatih berpikir dan bernalar, melalui kemampuan penalaran seseorang yang terus dilatih sehingga semakin berkembang, maka orang tersebut akan bertambah daya pikir dan pengetahuannya. Untuk itu diperlukan kreativitas belajar yang tinggi untuk mewujudkan hal tersebut karena kreativitas merupakan hal yang sangat penting dalam proses pembelajaran apalagi dalam mata pelajaran Fisika. Dilihat dari hasil penelitian yang dilaksanakan di SMAS Ferdy Ferry Kota Jambi bahwa siswa kelas XII IPA 3 dan siswa kelas XII IPA 4 sudah kreatif dalam proses pembelajaran fisika. Kreativitas belajar dapat dipengaruhi oleh faktor internal (dalm diri sendiri) dan juga faktor eksternal (dari lingkungan). Kreativitas dapat dikembangkan dengan mengkondisikan siswa untuk aktif terlibat langsung selama proses pembelajaran.

\section{REFERENSI}

Agus, M. W. 2013. Statistika Terapan. Konsep dan Aplikasi dalam Penelitian Bidang Pendidikan, Psikologi dan Ilmu Sosial Lainnya. Jakarta. PT Elex Media Komputindo.

Dilla, S. C., Hidayat, W., \& Rohaeti, E. E. 2018. Faktor Gender dan Resiliensi dalam Pencapaian Kemampuan Berpikir Kreatif Matematis Siswa SMA. Journal of Medives: Journal 
Jurnal Pendidikan Fisika dan Teknologi

of Mathematics Education IKIP

Veteran Semarang, 2(1), 129-136.

Hardiyanti, K., Astalini, A., \& Kurniawan, D. A. 2018. Sikap Siswa Terhadap Mata Pelajaran Fisika Di SMA Negeri 5 Muaro Jambi. EduFisika: Jurnal Pendidikan Fisika, 3(02), 112.

Hidayatullah, Z., Makhrus, M., \& Gunada, I. W. 2018. Analisis Tingkat

Kemampuan Berpikir Kritis

Gelombang Mekanik Melalui

Pembelajaran Dengan Pendekatan

Konflik Kognitif. Jurnal Pendidikan

Fisika dan Teknologi, 4(2), 151-157.

Istianah, E. 2013. Meningkatkan Kemampuan Berpikir Kritis Dan Kreatif Matematik Dengan Pendekatan Model Eliciting Activities (MEAS) Pada Siswa SMA. Infinity Journal, 2(1), 43-54.

Munandar, U. 2004. Pengembangan Kreativitas Anak Berbakat. Jakarta: Rineka Cipta.

Munandar, U. 2009. Pengembangan Kreativitas Anak Berbakat. Jakarta: Rineka Cipta.

Muschon. 2013. Statistik Deskriptif. Jakarta: Guepedia.

Pebriyanti, D., Sahidu, H., \& Sutrio. 2017. Efektifitas Model Pembelajaran Perubahan Konseptual Untuk Mengatasi Miskonsepsi Fisika pada Siswa Kelas X SMAN 1 Praya Barat Tahun Pelajaran 2012/2013. Jurnal Pendidikan Fisika dan Teknologi, 1(2), 92-96.

Sambada, D. 2012. Peranan kreativitas siswa terhadap kemampuan memecahkan masalah fisika dalam pembelajaran kontekstual. Jurnal Penelitian Fisika dan Aplikasinya (JPFA), 2(2), 37-47.

Smarabawa, I. G. B. N., Arnyana, I. B., \& Setiawan, I. G. A. N. (2013). Pengaruh model pembelajaran sains teknologi masyarakat terhadap pemahaman konsep biologi dan keterampilan berpikir kreatif siswa
Volume 5 No.2, Desember 2019

SMA. Jurnal Pendidikan dan Pembelajaran IPA Indonesia, 3(1).

Sugihartono, Fathiyah, K.N., Setiawati, F. A., Harahap, F., \& Nurhayati, S.R. 2007. Psikologi Pendidikan. Yogyakarta, Uny Press.

Sukmadinata, N. S. 2003. Landasan psikologi proses pendidikan. Bandung: Remaja Rosdakarya.

Sutrio, Fitriani, N., \& Gunawan. 2017. Berpikir Kreatif Dalam Fisika Dengan Pembelajaran Conceptual Understanding Procedures (Cups) Berbantuan LKPD, Jurnal Pendidikan Fisika Dan Teknologi, 1(3), 24.

Yoga, R., W. 2013. Pengaruh Kreativitas Belajara Dan Sikap Kerja Siswa Terhadap Kesiapan Kerja Pada Siswa Kelas XII SMK Negeri 2 Pengasih. SKRIPSI. Universitas Negeri Yogyakarta. 